\title{
Hepatitis $G$ virus infection in chronic liver disease
}

M Guilera, J C Sáiz, F X López-Labrador, E Olmedo, S Ampurdanés, X Forns, J Bruix, A Parés, J M Sánchez-Tapias, M T Jiménez de Anta, J Rodés

\begin{abstract}
Background-The hepatitis $G$ virus (HGV), a recently identified member of the Flaviviridae family, can cause chronic infection in man but the role of this agent in chronic liver disease is poorly understood.

Aims-To evaluate the prevalence and meaning of HGV infection in a large series of patients with chronic liver disease. Subjects-Two hundred volunteer blood donors, 179 patients with chronic hepatitis C, 111 with chronic hepatitis $B, 104$ with alcoholic liver disease, 136 with hepatocellular carcinoma, and 24 with cryptogenic chronic liver disease were studied.

Methods-HGV RNA was investigated in serum samples by reverse transcription and polymerase chain reaction amplification of the $5^{\prime}$ non-coding region of $\mathrm{HCV}$ and hybridisation to a specific probe. The main features of HGV RNA seropositive and seronegative patients were compared. Results-The prevalence of HGV infection was $3 \%$ in blood donors, $7 \%$ in chronic hepatitis $C, 8 \%$ in chronic hepatitis $B, 2 \%$ in alcoholic liver disease, $4 \%$ in hepatocellular carcinoma, and $8 \%$ in cryptogenic chronic liver disease. HGV infected patients tended to be younger than noninfected patients but no differences concerning sex, possible source of infection, clinical manifestations, biochemical and virological parameters, or severity of liver lesions were found.

Conclusions-The prevalence of HGV infection in chronic liver disease seems to be relatively low in our area. Infection with HGV does not seem to play a significant pathogenic role in patients with chronic liver disease related to chronic $\mathrm{HBV}$ or HCV infection or to increased alcohol consumption, or in those with cryptogenic chronic liver disease.

(Gut 1998;42:107-111)
\end{abstract}

Keywords: chronic liver disease; hepatitis $\mathrm{G}$ virus

Service of

Microbiology, Hospital Clínic, Department of Medicine, University of Barcelona Medical School, Barcelona, Spain

M T Jiménez de Anta

Correspondence to: Dr J M Sánchez-Tapias, Liver Unit, Hospital Clínic, Villarroel 170, 08036 Barcelona, Spain.

Accepted for publication 16 July 1997 identified member of the Flaviviridae family distantly related to hepatitis $\mathrm{C}$ virus $(\mathrm{HCV}) .^{1{ }^{2}}$ This virus can be transmitted efficiently by blood transfusion and by other parenteral mechanisms ${ }^{2-5}$ and transient and long lasting infections with $\mathrm{HGV}$ have been documented in man. ${ }^{2}$

HGV RNA sequences have been detected in a high proportion of volunteer blood donors. ${ }^{26}$ HGV RNA positive donors may present with minor increases in serum alanine aminotrans- ferase (ALT) but at least $50 \%$ of them do not present with any evidence of liver disease. On this basis, HGV does not appear to be highly pathogenic.

Infection with HGV has, however, also been detected in a high proportion of patients with idiopathic fulminant hepatitis, ${ }^{78}$ suggesting that HGV may be highly pathogenic in some cases. This possibility is still open to question since other studies have not disclosed a significant prevalence of $\mathrm{HGV}$ infection in this condition. ${ }^{9}{ }^{10}$

There is also controversy about the role of HGV infection in the pathogenesis of chronic liver disease. Preliminary surveys of patients with chronic liver disease showed that $\mathrm{HGV}$ is often detected in patients chronically infected with other hepatotropic viruses such as the hepatitis B virus (HBV) or HCV but more rarely in patients with cryptogenic liver disease. ${ }^{21112}$ Some studies have however found a relatively high prevalence of $\mathrm{HGV}$ infection in patients with cryptogenic chronic hepatitis, suggesting that this virus may be important in this condition. ${ }^{13}{ }^{14}$

To elucidate further the pathogenic role of HGV in chronic liver disease we investigated the prevalence of $\mathrm{HGV}$ infection and its associated features in 554 patients with different chronic liver diseases including representative series of patients with alcoholic liver disease and hepatocellular carcinoma.

\section{Patients and methods}

PATIENTS

Five hundred and fifty four patients with chronic liver disease and 200 consecutive first donation volunteer blood donors were studied. According to clinical, serological, and histopathological features, patients were separated into the following categories.

Chronic hepatitis $C$

This group included 179 patients (109 male and 70 female; mean age 50 years, range 19-83). Chronic hepatitis C was assessed by sustained elevation of ALT, histologically proved chronic inflammation of the liver, and positive tests for anti-HCV antibodies and for HCV-RNA in serum. Other causes of chronic liver disease were excluded.

\section{Chronic hepatitis B}

This group included 111 patients (92 male and 19 female; mean age 41 years, range 14-69) with chronic hepatitis B virus infection, as assessed by long lasting hepatitis B surface (HBsAg) antigenaemia and elevated ALT. Liver biopsy was performed in 71 cases. 
Alcoholic patients

This group included 104 patients ( 70 male and 34 female; mean age 43 years, range 22-76) who had consumed more than $80 \mathrm{~g}$ of ethanol per day for at least five years. HBsAg and anti$\mathrm{HCV}$ were negative in all cases. Liver biopsy showed minimal abnormalities or fatty infiltration in $43(41 \%)$, fatty infiltration and fibrosis in $14(13.5 \%)$, alcoholic hepatitis in 23 $(22.1 \%)$, hepatic cirrhosis in $21(20.2 \%)$, and chronic hepatitis in three $(3 \%)$.

Hepatocellular carcinoma

This group included 136 patients (91 male and 45 female; mean age 64 years, range 40-93) with hepatocellular carcinoma and underlying cirrhosis. The diagnosis of hepatocellular carcinoma was based on data from imaging techniques-ultrasonography, computed tomography, and/or hepatic arteriography-and confirmed by histopathological and/or cytological examinations. The aetiology of preexisting cirrhosis was known in 125 cases.

Cryptogenic chronic liver disease

This group included 24 patients (12 male and 12 female; mean age 45 years, range 19-75) years. All presented with abnormalities of liver function tests consisting mainly of elevation of aminotransferase serum levels 1.5 times above the upper normal limit lasting for at least one year. None were obese or alcoholic, and all denied use of potentially hepatotoxic drugs. All had negative tests for $\mathrm{HBsAg}$, anti-HCV, $\mathrm{HCV}$ RNA, and autoantibodies (antinuclear, antismooth muscle, antimitochondrial, and antiliver and kidney microsomes). Serum levels of iron, ferritin, caeruloplasmin, and $\alpha_{1}$-antitripsin were normal in all cases. Liver biopsy showed minimal changes in 10 cases, fatty liver in four, minimal cholestasis in two, chronic hepatitis in two, portal and periportal fibrosis in two, and micronodular cirrhosis in four.

\section{Blood donors}

Two hundred consecutive volunteer blood donors (114 male and 86 female; mean age 39 years, range 18-65) were studied at the time of their first donation.

SEROLOGICAL METHODS

$\mathrm{HBsAg}$, anti-HCV, and anti-HDV were tested with commercially available enzyme linked immunosorbent assay (ELISA) kits. HBVDNA in serum was investigated by polymerase chain reaction (PCR) amplification of $\mathrm{HBV}$ core sequences according to a simplified protocol reported previously. ${ }^{15}$

HCV RNA in serum was determined by reverse transcription (RT) and amplification by nested PCR of the $5^{\prime}$ non-coding region ( 5 'NCR) region of $\mathrm{HCV}$, as described previously. ${ }^{16} \mathrm{HCV}$ RNA serum levels were measured by a competitive PCR method recently developed in our laboratory. ${ }^{17}{ }^{18} \mathrm{HCV}$ genotype was determined according to Okamoto et $a l^{19}$ with some modifications, as described previously. ${ }^{20}$

HGV RNA in serum was determined as described previously. ${ }^{10} 18$ In brief, RNA was extracted from $140 \mu \mathrm{l}$ of serum using a commercially available kit (QiAmp, Qiagen, Hilden, Germany). Complementary DNA was synthesised from $15 \mu \mathrm{l}$ of extracted RNA by 60 minutes incubation at $37^{\circ} \mathrm{C}$ with $300 \mathrm{U}$ of Moloney leukaemia virus reverse transcriptase (Gibco-BRL, Gaithersburg, Maryland, USA), random primers, and $20 \mathrm{U}$ of ribonuclease inhibitor in a final volume of $30 \mu \mathrm{l}$ of RT buffer (50 mM Tris- $\mathrm{HCl}, \mathrm{pH} 8.3,75 \mathrm{mM} \mathrm{KCl}, 3 \mathrm{mM}$ $\mathrm{MgCl}_{2}, 10 \mathrm{mM}$ DTT, $0.01 \%$ gelatine, $200 \mathrm{mM}$ each deoxynucleotide). Specific PCR amplification and hybridisation of the 5 'NCR of the HGV genome was carried out using a commercial kit (Hepatitis G virus-Primer and capture probe set, Boehringer, Mannheim $\mathrm{GmbH}$, Mannheim, Germany) according to the manufacturer's instructions. One positive and three negative controls were included in each run. The background signal of negative controls ranged between 0.084 and 0.113 . Samples giving a signal five times above the mean background signal were considered positive. Results were accepted on agreement on repeated testing.

STATISTICAL ANALYSIS

Comparisons between groups were made by the $\chi^{2}$ or Fisher's exact test for categorical variables and by the Mann-Whitney test or Student's $t$ test when appropriate for quantitative variables. A p value less than 0.05 was considered significant.

\section{Results}

HGV INFECTION IN BLOOD DONORS

HGV RNA was detected in six of 200 blood donors $(3 \%)$. Anti-HCV was positive in two $(1 \%)$ and $\mathrm{HBs} A g$ in one $(0.5 \%)$. HGV infected donors were younger than non-infected donors (27 (5) versus 39 (14) years, $p=0.03$ ). None of the HGV infected donors had past history or clinical evidence of liver disease. ALT values were similar in $\mathrm{HGV}$ infected (32 (8) IU/l) and non-infected donors (29 (14) IU/1). A minimal elevation of ALT (45 IU) was detected in one of six $(17 \%) \mathrm{HGV}$ infected and in 28 of 194 (14\%) non-infected donors.

\section{HGV INFECTION IN PATIENTS WITH CHRONIC} HEPATITIS C

HGV RNA sequences were found in 12 of 179 patients $(6.7 \%)$. Although the prevalence of $\mathrm{HGV}$ infection in this group was higher than in blood donors the difference did not reach statistical significance. No significant differences between HGV infected and non-infected patients were observed concerning the demographic features, the presumed source of infection, the biochemical or haematological abnormalities, the degree of severity of liver lesions, the infecting HCV genotype, or the level of $\mathrm{HCV}$ viraemia (table 1 ).

HGV INFECTION IN PATIENTS WITH CHRONIC HBV INFECTION

HGV RNA was detected in nine of 111 patients $(8.1 \%)$. Although the prevalence of $\mathrm{HGV}$ infection in this group was higher than in blood donors the difference was not statisti- 
Table 1 Baseline features of patients with chronic hepatitis $C$ according to the presence or absence of $H G V-R N A$ sequences in serum

\begin{tabular}{llll}
\hline Characteristics & $\begin{array}{l}\text { HGV-RNA } \\
\text { negative }(n=167)\end{array}$ & $\begin{array}{l}\text { HGV-RNA } \\
\text { positive }(n=12)\end{array}$ & p Value \\
\hline Age (y) & $50(14)$ & $49(17)$ & $\mathrm{NS}$ \\
Sex (male/female) & $102 / 65$ & $7 / 5$ & $\mathrm{NS}$ \\
Presumed source of infection & $51(30 \%)$ & $3(25 \%)$ & $\mathrm{NS}$ \\
$\quad$ Blood transfusion & $15(9 \%)$ & $2(17 \%)$ & \\
$\quad$ Addiction to i.v. drugs & $101(61 \%)$ & $7(58 \%)$ & $\mathrm{NS}$ \\
$\quad$ Unknown & $5.6(1.8)$ & $4.1(2.3)$ & $\mathrm{NS}$ \\
WBC count $\left(\times 10^{9} / 1\right)$ & $152(55)$ & $125(65)$ & $\mathrm{NS}$ \\
Platelet count $\left(\times 10^{9} / 1\right)$ & $92(61)$ & $95(80)$ & $\mathrm{NS}$ \\
AST (IU/l) & $151(115)$ & $186(151)$ & $\mathrm{NS}$ \\
ALT (IU/l) & $52(44)$ & $32(15)$ & $\mathrm{NS}$ \\
$\gamma$-glutamyl transferase (IU/1) & $0.9(1.01)$ & $1.0(0.7)$ & \\
Bilirubin (mg/dl) & $55(33 \%)$ & $2(16 \%)$ & \\
Degree of histological severity & $50(30 \%)$ & $4(33 \%)$ & \\
$\quad$ Mild hepatitis & $18(11 \%)$ & $2(16 \%)$ & \\
Moderate hepatitis & $44(26 \%)$ & $4(33 \%)$ & \\
Severe hepatitis & $131(80 \%)$ & $8(67 \%)$ & $\mathrm{NS}$ \\
$\quad$ Cirrhosis & $33(20 \%)$ & $4(33 \%)$ & $\mathrm{NS}$ \\
Virological features & $0.418(0.873)$ & $1.105(1.719)$ & $\mathrm{NS}$ \\
$\quad$ Genotype $1 \mathrm{~b}$ & Other genotypes & & \\
HCV viraemia (copies/ml $\left.\times 10^{6}\right)$ & &
\end{tabular}

Quantitative variables are expressed as mean (SD). Categorical variables are expressed as n (\%).

Table 2 Baseline features of patients with chronic HBV infection according to the presence or absence of HGV-RNA sequences in serum

\begin{tabular}{llll}
\hline Characteristics & $\begin{array}{l}\text { HGV-RNA } \\
\text { negative }(n=102)\end{array}$ & $\begin{array}{l}\text { HGV-RNA } \\
\text { positive }(n=9)\end{array}$ & p Value \\
\hline Age (y) & $41(13)$ & $36(5)$ & NS \\
Sex (male/female) & $86 / 16$ & $6 / 3$ & NS \\
Presumed source of infection & $1(1 \%)$ & $1(11 \%)$ & \\
$\quad$ Blood transfusion & $2(2 \%)$ & $1(11 \%)$ & \\
Addiction to i.v. drugs & $19(19 \%)$ & $1(11 \%)$ & \\
Intrafamilial & $6(5 \%)$ & $4(44 \%)$ & \\
Male homosexuality & $74(67 \%)$ & $2(22 \%)$ & NS \\
Unknown & $5.9(1.8)$ & $5.5(1.7)$ & NS \\
WBC count $\left(\times 10^{9} / 1\right)$ & $156(47)$ & $163(61)$ & NS \\
Platelet count $\left(\times 10^{9} / 1\right)$ & $70(54)$ & $63(29)$ & NS \\
AST (IU/l) & $125(118)$ & $111(91)$ & NS \\
ALT (IU/l) & $45(47)$ & $28(7)$ & NS \\
$\gamma$-glutamyl transferase (IU/l) & $0.8(0.3)$ & $0.6(0.4)$ & \\
Bilirubin (mg/dl) & & & \\
Degree of histological activity & $16(23 \%)$ & $2(29 \%)$ & \\
Mild hepatitis & $22(31 \%)$ & $1(14 \%)$ & NS \\
Moderate hepatitis & $22(31 \%)$ & $3(43 \%)$ & NS \\
Severe hepatitis & $8(11 \%)$ & $1(14 \%)$ & NS \\
Liver cirrhosis & $64(63 \%)$ & $4 / 9(44 \%)$ & NS \\
Other virological markers & $2(2 \%)$ & $1 / 9(11 \%)$ & \\
HBV-DNA positive & $11(13 \%)$ & $2 / 9(22 \%)$ & \\
Anti-HDV positive & Anti-HCV positive & &
\end{tabular}

Quantitative variables are expressed as mean (SD). Categorical variables are expressed as $\mathrm{n}(\%)$.

Table 3 Baseline features of patients with liver cirrhosis and hepatocellar carcinoma according to the presence or absence of HGV-RNA sequences in serum

\begin{tabular}{|c|c|c|c|}
\hline Characteristics & $\begin{array}{l}H G V-R N A \\
\text { negative }(n=131)\end{array}$ & $\begin{array}{l}H G V-R N A \\
\text { positive }(n=5)\end{array}$ & $p$ Value \\
\hline Age (y) & $64(9)$ & $57(9)$ & NS \\
\hline Sex (male/female) & $88 / 43$ & $3 / 2$ & NS \\
\hline Aetiology of cirrhosis & & & NS \\
\hline Alcoholic & $11(8 \%)$ & $1(20 \%)$ & \\
\hline $\mathrm{HCV}$ infection & $78(60 \%)$ & $2(40 \%)$ & \\
\hline HBV infection & $4(3 \%)$ & 0 & \\
\hline HCV and HBV infection & $5(4 \%)$ & 0 & \\
\hline Alcoholic and HCV infection & $20(15 \%)$ & $1(20 \%)$ & \\
\hline Alcoholic and HBV infection & $2(2 \%)$ & 0 & \\
\hline $\mathrm{PBC}$ and $\mathrm{HCV}$ infection & 0 & $1(20 \%)$ & \\
\hline Cryptogenic & $11(8 \%)$ & 0 & \\
\hline Presumed source of infection & & & NS \\
\hline Blood transfusion & $35(27 \%)$ & $4(80 \%)$ & \\
\hline Unknown & $96(73 \%)$ & $1(20 \%)$ & \\
\hline WBC count $\left(\times 10^{9} / 1\right)$ & $5.9(4.1)$ & $5.4(2.4)$ & NS \\
\hline Platelet count $\left(\times 10^{9} / 1\right)$ & $107(53)$ & $107(58)$ & NS \\
\hline AST (IU/1) & $115(130)$ & $149(120)$ & NS \\
\hline ALT (IU/1) & $106(117)$ & $158(121)$ & NS \\
\hline Alkaline phosphatase (IU/l) & $290(239)$ & 247 (119) & NS \\
\hline$\gamma$-glutamyl transferase (IU/l) & $118(145)$ & $149(114)$ & NS \\
\hline Bilirubin (mg/dl) & $2.2(2.2)$ & $3.3(3)$ & NS \\
\hline
\end{tabular}

Quantitative variables are expressed as mean (SD). Categorical variables are expressed as $\mathrm{n}(\%)$. PBC, primary biliary cirrhosis. cally significant. As shown in table 2 comparison of $\mathrm{HGV}$ infected and non-infected patients did not show significant differences concerning demographic features, biochemical and haematological abnormalities, severity of liver lesions, level of detectable HBV replication, or infection with other hepatotropic viruses such as HDV and HCV. The presumed source of infection was also similar. However, a high rate of $\mathrm{HGV}$ infection (four of 10) was observed among HBV infected male homosexuals.

HGV INFECTION IN PATIENTS WITH ALCOHOLIC

LIVER DISEASE

HGV RNA was detected in two of 104 patients $(1.9 \%)$. Statistical analysis was not possible due to the small number of HGV-RNA positive patients. One was a 39 year old woman without clinical evidence of liver disease and slightly abnormal liver function tests (serum aspartate aminotransferase (AST) 60 IU/1, ALT 38 IU/1, alkaline phosphatase $149 \mathrm{IU} / \mathrm{l}, \gamma$-glutamyl transferase $76 \mathrm{IU} / 1$, bilirubin $0.8 \mathrm{mg} / \mathrm{dl}$, serum albumin $42 \mathrm{~g} / \mathrm{l}$, prothrombin time $100 \%$ ) in whom liver biopsy showed mild fatty infiltration of the liver. The other was a 51 year old man with hepatic cirrhosis and abnormal liver function tests. None had a history of blood transfusion or intravenous drug misuse. Eight of 102 HGV-RNA negative patients had received blood transfusions in the past.

\section{HGV INFECTION IN PATIENTS WITH}

HEPATOCELLULAR CARCINOMA

HGV RNA was detected in five of 136 patients $(3.7 \%)$. This prevalence is almost identical to that found in blood donors. HGV infected patients tended to be younger than noninfected patients. A history of blood transfusion prior to diagnosis of liver disease was more frequent in $\mathrm{HGV}$ infected patients. However, statistical analysis did not show significant differences between the two groups of patients concerning demographic features, presumed aetiology of underlying cirrhosis, presumed source of infection, or haematological and biochemical features (table 3). HGV-RNA was detected in association with $\mathrm{HCV}$ infection in four of the five cases.

HGV INFECTION IN PATIENTS WITH CRYPTOGENIC CHRONIC LIVER DISEASE

HGV RNA was detected in two of 24 patients $(8.3 \%)$. One was an asymptomatic 55 year old woman with slight ALT elevation lasting for seven years after recovery from an episode of fulminant hepatitis of unknown aetiology. The patient had received blood products at that time. The other was a 19 year old man with abnormal liver function tests in whom liver biopsy showed evidence of chronic hepatitis with mild activity and minimal fibrosis. A possible source of infection was not identified in this patient. Further analysis was not possible due to the small number of $\mathrm{HGV}$ infected patients detected in this group.

\section{Discussion}

$\mathrm{HGV}$, or GBV-C, is a recently identified member of the Flaviviridae family that can cause 
acute and chronic infection in man. ${ }^{12}$ The recent development of sensitive laboratory techniques for determination of HGV RNA sequences in clinical specimens has led to intensive investigation of the frequency and meaning of $\mathrm{HGV}$ infection in different clinical conditions. Despite many efforts, however, important aspects of the epidemiology and pathogenicity of $\mathrm{HGV}$ infection and its role in acute and chronic liver diseases still remain obscure.

In the current study we investigated the presence of HGV RNA infection in a large series of patients with a variety of chronic liver diseases and in a group of volunteer blood donors living in the same geographical area. The main demographic, epidemiological, clinical, and histopathological features in HGV infected and non-infected patients were analysed.

It is now clear that patients heavily exposed to blood and blood products, such as haemophiliacs, thalassaemics, and liver transplanted patients, ${ }^{6} 10132122$ as well as those at high risk of parenteral exposure, such as patients on haemodialysis ${ }^{23} 24$ and intravenous drug users, ${ }^{325}$ have the highest prevalence of HGV infection. These data suggest that parenteral exposure plays an important role in the transmission of HGV. This study showed, however, that a substantial proportion of HGV infected patients with chronic liver disease did not have a history of overt parenteral exposure, suggesting that $\mathrm{HGV}$ could also be transmitted by other routes. Furthermore, irrespective of the clinical or histological diagnosis, most of these patients also had evidence of infection by other parenterally transmitted hepatotropic viruses, such as $\mathrm{HCV}, \mathrm{HBV}$, or both, suggesting that HGV may also spread through nonapparent parenteral exposure. Interestingly, four of the nine patients coinfected with $\mathrm{HGV}$ and HBV were male homosexuals and did not have associated risk factors. This observation suggests that HGV may be sexually transmitted, as recently reported. ${ }^{25}$

Despite a similar epidemiological background, the prevalence of $\mathrm{HGV}$ infection in patients with chronic hepatitis C observed in this study was approximately two times higher than that in those with hepatocellular carcinoma, most of whom were also infected with $\mathrm{HCV}$. The reason for this difference is unclear. One possible explanation could be that chronic HGV infection may subside with time, leading to clearance of HGV RNA, as seems to occur in patients with haematological disorders ${ }^{6}$ and in intravenous drug misusers infected with HIV. ${ }^{25}$ This is likely because the patients with cancer were older and, possibly, had more long lasting viral infection than those with chronic hepatitis. The observation that HGV RNA was detected in young rather than in middle aged blood donors, further supports this hypothesis.

Data on the pathogenic effects of HGV are controversial. HGV infection is the only agent identified in some patients with acute sporadic non-A, non-E hepatitis, ${ }^{2}$ idiopathic fulminant hepatitis, ${ }^{78}$ or cryptogenic chronic liver disease. ${ }^{14}$ Studies in blood donors ${ }^{2}$ and in haemodialysis patients, ${ }^{423}$ however, have clearly shown that HGV infection is frequently found in subjects without clinical or biochemical evidence of liver disease. In a recent study in haemodialysis patients, HGV infected patients did not usually present with liver abnormalities except if coinfected with other hepatotropic viruses. $^{24}$

Mild elevation of ALT is often found in $\mathrm{HGV}$ infected blood donors. ${ }^{2}$ In this study, a minimal elevation of ALT was observed in one of the six blood donors in whom HGV RNA was detected in serum, but this abnormality was also observed in a similar proportion of HGV non-infected donors and may be a non-specific finding.

In agreement with previous observations, ${ }^{18} 2627$ infection with HGV did not appear to increase the severity of liver lesions in patients with chronic liver disease resulting from $\mathrm{HBV}$ or $\mathrm{HCV}$ infection. On the other hand, there is increasing evidence indicating that coexisting $\mathrm{HGV}$ infection does not appear to modify the response to interferon in patients with chronic hepatitis C. ${ }^{1826} 27$ These data support the hypothesis that HGV coinfection does not play a relevant role in the pathogenesis of $\mathrm{HBV}$ or HCV induced chronic liver disease. Further evidence against the pathogenicity of HGV was recently provided by a study of patients with acute post-transfusional hepatitis, showing that combined infection with HGV and HCV did not produce more severe hepatitis than infection with HCV alone. ${ }^{28}$

Although $\mathrm{HGV}$ infection often becomes chronic, chronic hepatitis does not appear to develop in subjects persistently infected with $\mathrm{HGV}$ alone, as recently shown in patients with acute non-A, non-E hepatitis. ${ }^{29}$ In the current study, the prevalence of HGV RNA in patients with chronic liver disease unrelated to $\mathrm{HCV}$ or HBV infection, including patients with cryptogenic disease and patients with cryptogenic cirrhosis and hepatocellular carcinoma, was similar to that observed in healthy volunteer blood donors and in patients with alcoholic liver disease. Thus, $\mathrm{HGV}$ does not seem to be involved in cryptogenic liver diseases in our geographical area.

Supported in part by grants $94 / 098$ from FIS of the Ministerio de Sanidad and SAF97-0103 from CICYT. M Guilera, F X López-Labrador, E Olmedo, and S Ampurdanés were supported by Fundació Privada Clínic.

1 Simons JN, Leary TP, Dawson GJ, Pilot-Matias TJ, Muerhoff AS, Schlauder GG, et al. Isolation of a novel virus-like sequence associated with human hepatitis. Nat Med 1995; sequence $1: 564-9$.

2 Linnen J, Wages J, Zhong-Keck Z-Y, Fry KE, Krawczynski $\mathrm{KZ}$, Alter $\mathrm{H}$, et al. Molecular cloning and disease association of hepatitis $\mathrm{G}$ virus: a transfusion-transmissible agent. Science 1996;271:505-8

3 Aikawa T, Sugai Y, Okamoto H. Hepatitis G virus in drug abusers with chronic hepatitis C [letter]. $N$ Engl f Med 1996;334:195-6.

4 Masuko K, Mitsui T, Iwano K, Yamazaki C, Okuda K, Meguro $\mathrm{T}$, et al. Infection with hepatitis GB virus $\mathrm{C}$ in patients on maintenance hemodialysis. N Engl f Med 1996; 334:1485-90.

5 Schmidt B, Korn K, Fleckenstein B. Molecular evidence for transmission of hepatitis $\mathrm{G}$ virus by blood transfusion [lettransmission of hepatitis $\mathrm{G}$

6 Jarvis LM, Davidson F, Hanley JP, Yap PL, Ludlam CA, Simmonds P. Infection with hepatitis $G$ virus amon recipients of plasma products. Lancet 1996;348:1352-5. 
7 Yoshiba M, Okamoto H, Mishiro S. Detection of the GBV-C hepatitis virus genome in serum from patients with fulminant hepatitis of unknown aetiology. Lancet 1996;346: 1131-2.

8 Heringlake S, Osterkamp S, Trautwein Ch, Tillmann HL, Böker K, Muerhoff S, et al. Association between fulminant hepatic failure and a strain of GBV virus C. Lancet 1996;348:1626-9.

9 Tameda Y, Kosaka Y, Tagawa S, Takase K, Sawada N, Nakao $\mathrm{H}$, et al. Infection with GB virus $\mathrm{C}(\mathrm{GBV}-\mathrm{C})$ in patients with fulminant hepatitis. F Hepatol 1996;25:842-7. 10 Saiz JC, Sans M, Mas A, Olmedo E, Lopez-Labrador FX, hepatic failure. Gut 1997;41:696-9.

11 Nakatsuji Y, Shih JWK, Tanaka E, Wages J, Kiyosawa K, Kim JP, et al. Prevalence of hepatitis G virus (HGV) in Japan [abstract]. Hepatology 1995;22:82A

12 Hadzayannis SJ, Dawson GJ, Vrettou E, Gioustozi A, Schlauder G, Desai S. Infection with the novel GB-C virus in multiply transfused patients and in various forms of in multiply transfused patients and in various forms of

13 Hoofnagle JH, Lombardero M, Wei Y, Yun AJ, Yang L, Kim Hoofnagle $\mathrm{JH}$, Lombardero M, Wei Y, Yun AJ, Yang L, Kim
JP. Hepatitis $\mathrm{G}$ virus (HGV) infection before and after liver transplantation for fulminant hepatic failure $(\mathrm{FHF})$ and cryptogenic cirrhosis [abstract]. Hepatology 1996;24:189A.

14 Fiordalisi G, Zanella I, Mantero G, Bettinardi A, Stellini R, Paraninfo G, et al. High prevalence of GB virus $C$ infection in a group of Italian patients with hepatitis of unknown etiology. F Infect Dis 1996;174:181-3.

15 Costa J, López-Labrador FX, Sánchez-Tapias JM, Mas A Vilella A, Olmedo E, et al. Microwave treatment of serum facilitates detection of hepatitis $\mathrm{B}$ virus DNA by the polymerase chain reaction. Results of a study in anti- $\mathrm{HBe}$ positive chronic hepatitis B. F Hepatol 1995;22:35-42.

16 Sánchez-Tapias JM, Forns X, Ampurdanés S, Titó Ll, Planas R, Viver JM, et al. Low dose alpha interferon therapy can be effective in chronic hepatitis C. Results of a multicentre, randomised trial. Gut 1996;38:603-9.

17 Olmedo E, Costa J, López-Labrador FX, Forns X, Guilera M, Ampurdanés S, et al. Comparison of two quantitative HCV RNA assays. Evolution of viremia in short term [abstract]. Hepatology 1996;24:384A

18 Saiz JC, Ampurdanés S, Olmedo E, López-Labrador FX, Forns X, Guilera M, et al. Hepatitis G virus infection in chronic hepatitis $\mathrm{C}$ : frequency, features and response to interferon therapy. $\mathcal{f}$ Hepatol 1997;26:787-93.

19 Okamoto $\mathrm{H}$, Sugiyma Y, Okada S, Kurai K, Akahane Y, Sugai $Y$, et al. Typing hepatitis $C$ virus by polymerase chain reaction with type-specific primers: application to clinical surveys and tracing infectious sources. F Gen Virol 1992;73:673-9.

20 Forns X, Maluenda M, López-Labrador FX, Ampurdanés $\mathrm{S}$, Olmedo E, Costa J, et al. Comparative study of three methods for genotyping hepatitis C virus strains in samples from Spanish patients. F Clin Microbiol 1996;34:2516-21.

21 Tagarielo G, Davoli PG, Traldi A. Hepatitis G viral RNA in Italian haemophiliacs with and without hepatitis $C$ infection. Lancet 1996;348:760-1.

22 Belli LS, Idéo G, Silini E. Hepatitis G virus and post-transplantation hepatitis. $N$ Engl f Med 1996:335: 1394-5.

23 Sampietro M, Badalamenti S, Graziani G, Como G, Buccianti $G$, Corbetta N, et al. Hepatitis $G$ virus infection in hemodialysis patients. Kidney Int 1997;51:348-52.

24 Forns X, Fernandez-Llama P, Costa J, Lopez-Labrador FX, Ampurdanés S, Olmedo E, et al. Hepatitis $\mathrm{G}$ virus infection in a hemodyalisis unit: prevalence and clinical implications. Nephrol Dial Transpl 1997;12:956-60.

25 Stark K, Bienzle U, Hess G, Engel AM, Hegenscheid B, Schlüter V. Detection of the hepatitis $G$ virus genome among injecting drug users, homosexual and bisexual men and blood donors. F Infect Dis 1996;174:1320-3.

26 Tanaka E, Alter HJ, Yoshiyuki N, Shih WK, Kim JP, Matsumoto $\mathrm{A}$, et al. Effect of hepatitis $\mathrm{G}$ virus infection on chronic hepatitis C. Ann Intern Med 1996;125:740-3.

27 Berg T, Dirla U, Naumann U, Heuft HG, Küther S, Lobeck $\mathrm{H}$, et al. Responsiveness to interferon alpha treatment in patients with chronic hepatitis $\mathrm{C}$ coinfected with hepatitis G virus. F Hepatol 1996;25:763-8.

28 Alter HJ, Nakatsuji Y, Melpolder J, Wages J, Wesley R, Shih $\mathrm{JW}$, et al. The incidence of transfusion-associated hepatitis $\mathrm{G}$ virus infection and its relation to liver disease. $N$ Engl $\mathcal{F}$ Med 1997;336:747-54.

29 Alter MJ, Gallagher M, Morris TT, Moyer LA, Meeks EL, Krawczynski K, et al. Acute non-A-E hepatitis in the United States and the role of hepatitis $G$ virus infection. Sentinel Counties Viral Hepatitis Study Team. N Engl $\mathcal{F}$ Med 1997;336:741-6. 